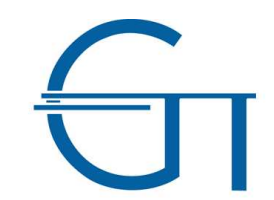

The Hellenic Observatory

The European Institute

\title{
Taxation and Capital Structure: evidence from a transition economy
}

Leora Klapper and Konstantinos Tzioumis

GreeSE Paper No 16

Hellenic Observatory Papers on Greece and Southeast Europe

July 2008 


\section{Table of Contents}

ABSTRACT__ iii

1. Introduction __ 1

2. Motivation__ 4

3. Data and empirical methodology__ 8

4. Analysis of results __ 13

5. Conclusions _ 17

References

\section{Acknowledgements}

The authors thank Thorstern Beck, Jennifer Blouin, Valentina Bruno, Stijn Claessens, Asli Demirguc-Kunt, Christian Leuz, Sanja Madzarevic-Sujster, and Vassilis Monastiriotis for helpful comments. The opinions expressed do not necessarily represent the views of the World Bank, its Executive Directors, or the countries they represent. 


\title{
Taxation and Capital Structure: evidence from a transition economy
}

\author{
Leora Klapper\# and Konstantinos Tzioumis*
}

\begin{abstract}
We examine the effect of taxation on financing policy using the corporate tax reform in 2001 in Croatia as a natural experiment. Since the extant literature on tax effects on capital structure studies listed firms in developed countries, it is worth investigating whether the same results apply to privately-held, small and medium sized firms (SMEs) in transition economies. The findings provide significant evidence that lower taxes affected the capital structure of Croatian firms, which resulted in increased equity levels and decreased long-term debt levels. We also find that smaller and more profitable firms were more likely to reduce their debt levels. These findings are consistent with the trade-off theory of capital structure, which suggests that lower taxes decrease the incentive to hold debt due to decreasing interest tax deductibility.
\end{abstract}

Keywords: Capital structure; Taxation; Transition Economies.

\footnotetext{
\# Development Research Group, The World Bank, 1818 H Street, NW, Washington, DC 20433, USA Email: 1klapper@worldbank.org

* Hellenic Observatory, European Institute, London School of Economics, London, WC2A 2AE, UK Email: k.tzioumis@1se.ac.uk

Correspondence: Konstantinos Tzioumis, Hellenic Observatory, European Institute, London School of Economics, London, WC2A 2AE, UK, Email: k.tzioumis@1se.ac.uk
} 



\section{Taxation and Capital Structure: evidence from a transition economy}

\section{Introduction}

During the last decade, there has been a wave of tax system reforms across Eastern Europe. Although economic models predict a variety of effects from corporate taxation in terms of factor allocation, financing choices and investment patterns, there is little empirical evidence from transition economies. Our study contributes in this field by investigating the unique case of Croatia's corporate tax reform in 2001 and its effect on the capital structure of private firms. Focusing on private SMEs, we find that equity levels were increased while long-term debt levels were decreased following the substantial reduction of the corporate tax rate from $35 \%$ to $20 \%$.

Interestingly, among the determinants of capital structure, taxation is probably the most debated. According to the influential trade-off theory of debt, the optimal level of debt in a firm's capital structure is determined by the balance of the tax shield provided by debt and the present value of financial distress costs (Myers, 2003). More specifically, there is positive relationship between the corporate tax shield and firm value given that each increase in the debt portion of a firm's capital structure decreases the after-tax cash flow. On the 
other hand, when excessive amount of debt has been accumulated by the firm, it risks a default resulting in the transfer of control to the creditors and the incurrence of deadweight costs which further reduce firm value (Frank and Goyal, 2008). Thus, the lower the tax advantages of debt, the lower the optimal debt-equity ratio.

Despite trade-off theory's straightforward appeal, empirical tests have produced mixed results. More specifically, the empirical evidence for a taxeffect on capital structure has been less than definitive due to (a) the difficulty of calculating accurately the marginal tax benefits, which are influenced by non-debt tax shields and various tax rules, and (b) the limited availability of non-US firm data on statutory corporate tax reforms. Regarding empirical tests, Givoly et al. (1992) find a positive relation between changes in US corporate taxes and changes in leverage, as well as a substitution effect between debt and non-debt tax shields as a result of the Tax Reform Act of 1986. Graham and Harvey (2001) interview 392 CFOs in the U.S. and find that the tax advantage of interest deductibility is of significant concern by CFOs in large, regulated, and dividend-paying firms. Ayers et al. (2001), using a sample of small U.S. firms (i.e., <500 employees), find a negative relationship between effective tax rate and debt. In particular, they find a negative effect of marginal tax rates on the use of outside debt (loans from non-owners), and no effect of marginal tax rates on the use of inside debt (loans from owners). Notably, this evidence comes exclusively from publicly listed U.S. firms. As with many aspects of firm financing, bankruptcy costs and asymmetric information in financing 
decisions of firms in transition and developing countries remain unclear (Prasad et al., 2005).

Figure 1 Distribution of effective average tax rates in Croatia pre- and postthe corporate tax reform

(A) BEFORE CORPORATE TAX REFORM

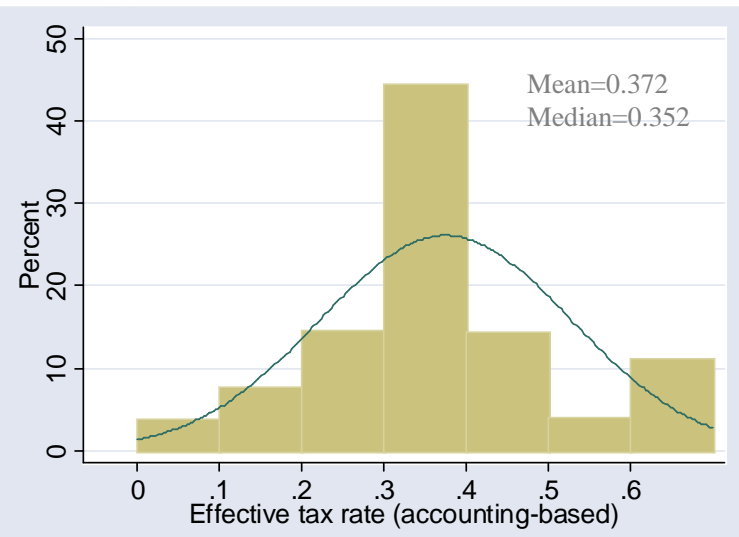

(B) AFTER CORPORATE TAX REFORM

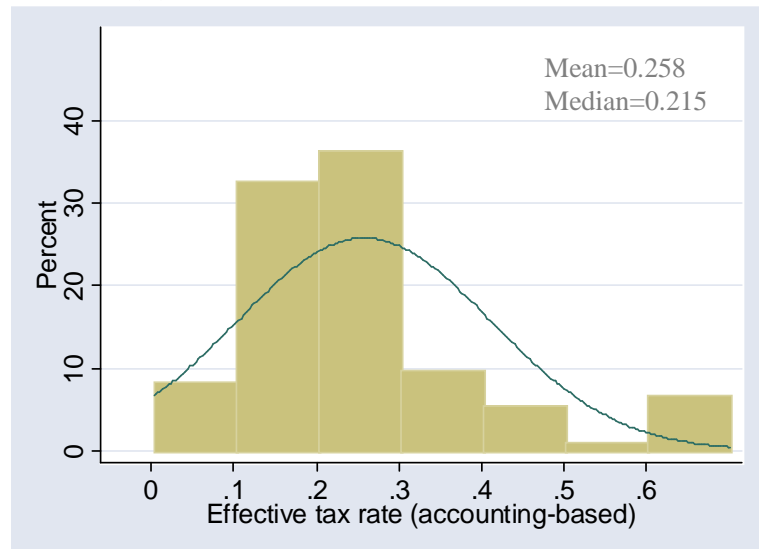

Note: The distributions are derived from the sample of 14,049 firms utilized in the paper. 'Before' and 'After' corporate tax reform refer to 1998-1999 and 2002-2003 periods, respectively.

Figure 2 Distribution of 'Equity to Assets' ratio in Croatia pre- and postthe corporate tax reform

(A) BEFORE CORPORATE TAX REFORM

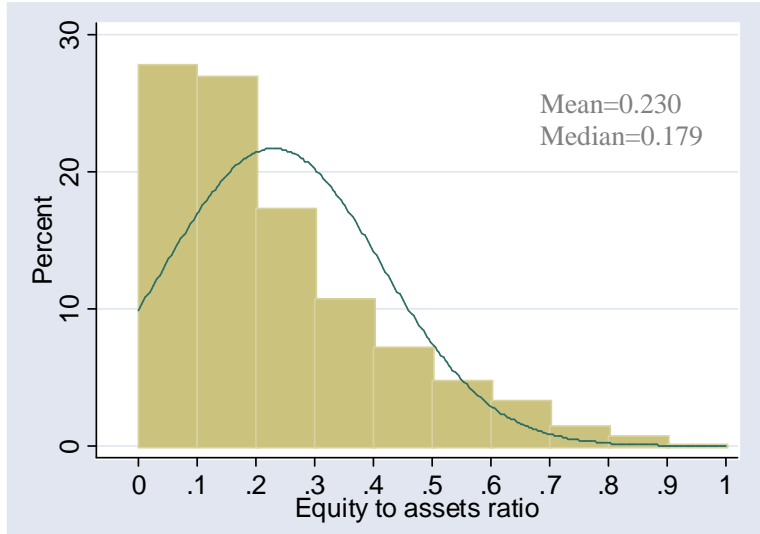

(B) AFTER CORPORATE TAX REFORM

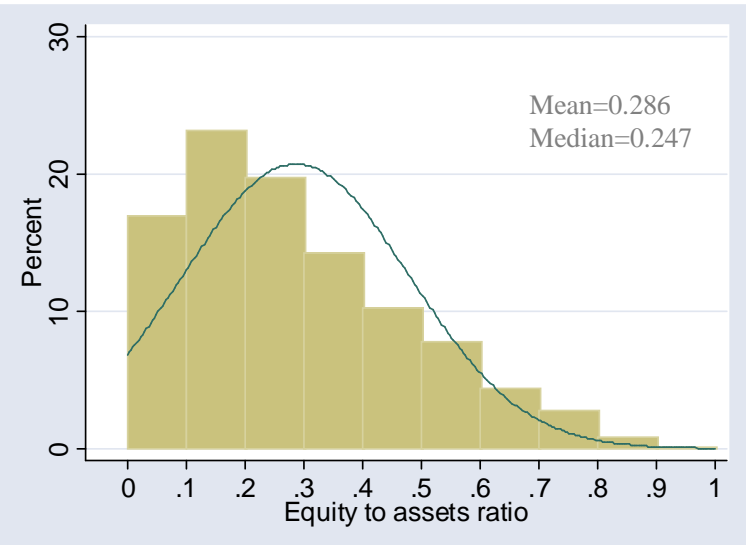

Note - The distributions are derived from the sample of 14,049 firms utilized in the paper. 'Before' and 'After' tax reform refer to 1998-1999 and 2002-2003 periods, respectively.

Using data on Croatian firms, this paper contributes to the literature by demonstrating that - in line with the trade-off theory of debt - firms increased their equity levels as a result of a corporate tax reform. In 2001, Croatia drastically cut its corporate tax rate from $35 \%$ to $20 \%$, primarily to promote 
private sector growth and attract foreign investment [Note: The General Tax Law (NN No. 127/00), that contained the Law on Corporate Profit Tax, was voted in December 2000 and took effect in January 1, 2001]. This exogenous change in the statutory tax rate was immediately translated into a lower effective tax rate (i.e., taxes divided by pre-tax income). Using the sample of Croatian firms in this study, Figures 1 and 2 illustrate how the mean and median effective tax rate dropped substantially, while the ratio of 'Equity-toAssets' increased, after the corporate tax reform. These changes provide an intuitive indication of a possible relation that ought to be tested further controlling for firm characteristics in order to account for firm-specific factors influencing the choice of capital structure.

The remainder of the paper is structured as follows. Section 2 outlines the motivation for this study. Section 3 describes the sample design and estimation methodology while Section 4 presents the findings. Section 5 concludes.

\section{Motivation}

There are several reasons for which the Croatian corporate tax reform offers a unique natural experiment on the impact of corporate taxes on firms' capital structure choice due to decreased interest tax deductibility:

First, cases of substantial corporate tax changes without concurrent changes in personal taxation are unusual, and economic research has traditionally dealt with minor changes in corporate tax policy that yielded mixed findings 
(Auerbach, 2002). In the United States, the Tax Reform Act of 1986 had mixed results because the maximum statutory tax rate decreased from $46 \%$ in 1986 to $34 \%$ after 1988, but simultaneous changes in several tax rules raised the fraction of corporate income taxable at the maximum rate (Gordon and MacKie-Mason, 1990). In developed European countries, corporate tax reforms have occurred, albeit either gradually (e.g., France after 1985) or with policy reversions, which complicate the study of a tax effect (e.g., in 2001, Italy substantially reversed the corporate tax reforms of 1997). Similarly, the wave of flat-tax reforms in Eastern Europe in the context of tax competition with the aim to boost economic growth and foreign direct investment is difficult to evaluate in terms of firms' capital structure choice since these corporate tax changes happened either too recently to evaluate (e.g., Slovakia in 2004, Romania in 2005) or simultaneously with dramatic overhauls of the personal taxation systems (e.g., Estonia, Latvia and Lithuania in the 1990s).

Second, since the literature on tax effects on capital structure deals with listed firms in developed countries, it is worth investigating whether the same results apply to SMEs in transition economies. Smaller private firms have higher bankruptcy costs and face different agency problems than publicly listed firms, thus influencing debt capacity and the ability to increase equity (Ang, 1992). At the same time, in transition economies the banking sector is often the sole avenue for external finance since alternative external financing mechanisms are underdeveloped. 
Third, the 2001 tax reform in Croatia extended little to personal taxation, thus making it easier to identify a corporate tax effect on firm financing. ${ }^{1}$ Although, a number of special allowances and separate schedules were announced for certain groups of taxpayers (Urban, 2006), the aggregate amount of personal tax reliefs in constant prices remained roughly the same during the 2001-2004 period (Bratic, 2006). Also, except for the highest income quintile, the changes in the standard tax schedule did not affect the actual average personal tax rate (Bratic, 2006). Moreover, despite a change in dividend taxation (i.e., before the reform, dividends and shares in profit were tax exempt, while after the reform they were taxed at the rate of 15 percent), it is unclear whether this change affected entrepreneurs' decision to receive income in the form of salary rather than dividends, given that the corresponding tax brackets of the personal income taxation were equal or higher compared to the dividend tax (i.e. 15\%$25 \%-35 \%$ versus $15 \%)^{2}$

Fourth, the elimination of the 'Allowance for Corporate Equity' (ACE) scheme in 2001 does not adversely affect our results. On the contrary, since the ACE allows neutrality between finance by debt and finance by equity (Devereux and Sorensen, 2005; Keen and King, 2002), the elimination of ACE would create a debt-bias, typical of standard tax systems, thus allowing a stronger test of the corporate tax reform's positive effect on the equity choice of Croatian firms.

\footnotetext{
${ }^{1}$ The tax advantage of debt is increasing in the corporate tax rate and decreasing in the personal tax rate (Miller, 1977). This is because, at the personal level, interest income is taxed at a rate that is typically higher than the tax rate on returns from common stock. Thus, holding personal taxation constant, the effect from corporate tax rate reform would be unambiguous.

${ }^{2}$ Similarly, the introduction of the dividend tax does not necessarily lead corporations to finance their activities largely through retained earnings (Poterba and Summers, 1985; Zodrow, 1991).
} 
Another important issue is that the elimination of the ACE after 2001 did not broaden the tax base substantially; Klemm (2007) suggests that there is weak evidence that ACE in Croatia had an effect on tax revenues, while in Keen and King's (2002) review of Croatia's tax system, it is reported that $86.3 \%$ of the population of profitable firms in 1998 was subject to taxation after estimating the profit tax base with ACE. This could be attributed to the fact that the imputed rate on the equity under the ACE scheme was equal to 5 percent plus the inflation rate of industrial product prices, a rate that was deemed as rather low by many tax experts in Croatia (Svaljek, 2005), since the protective interest rate should ideally be equal to the interest rate on risk-free investments which is difficult to estimate in the absence of developed capital markets in Croatia in the 1990 s. $^{3}$

Fifth, Croatia's banking system quickly recovered after the brief crisis of 1998 , resulting in increased credit availability and decreased loan rates that enhanced the access and use of debt by firms (Kraft, 2000). In particular, the ratio of private credit to GDP increased from $38 \%$ in 1998 to $54 \%$ in 2004 , while bank long-term loan rates for enterprises decreased from $14.5 \%$ in 1998 to $6 \%$ in 2004. ${ }^{4}$ Also, the rapid development of the capital markets in Croatia provided equity capital to listed firms, thus easing bank-based financing for non-listed firms, which are the sole focus of this study. In this context of substantial financial developments, a possible decrease in the debt levels of Croatian firms

\footnotetext{
${ }^{3}$ Keen and Kling (2002) acknowledge this criticism, but suggest that the rate was about right (namely "not too high, not too low").

${ }^{4}$ Sources: World Bank, Croatian National Bank
} 
would strengthen our argument of a negative effect on debt financing due to the corporate tax reform. Furthermore, it is easier to investigate the effect of taxation changes in private Croatian companies because they did not have the size, organizational structure, or the global activity to receive cross-border finance, all of which would make them subject to alternative tax rules. ${ }^{5}$

\section{Data and empirical methodology}

We focus on the non-financial private sector in Croatia, using a sample of private (non-listed), unconsolidated, non-state-owned Croatian firms from the BvD Amadeus dataset (version: Jan. 2005). The data includes all formal-sector (registered) firms and was collected by Creditreform Croatia, which reports that the data in Amadeus covers about $33 \%$ of the private sector (the remainder is mostly informal firms). Amadeus' full coverage of Croatian firms begins in 1997. We create an unbalanced panel for 1998, 1999, 2002 and 2003, thus covering a period of two years before and after the corporate tax reform in 2001. We do not consider 2001 because firms may not have changed their capital structure in the first year of the reform due to the transaction time that is needed to issue new equity or debt. ${ }^{6}$ The period between 1998 and 2003 provides a unique window of opportunity to study the effect of corporate

\footnotetext{
${ }^{5}$ In contrast, large multinationals and dual-resident companies are typically engaging in cross-border tax arbitrage in order to take advantage of differences in corporate income tax rules between countries when double-taxation is absent. This extends to financing, where specific types of financing (e.g. international corporate bonds, currency swaps, hybrid instruments that have characteristics of both equity and debt) are sourced from countries with favourable tax conditions.

${ }^{6}$ Notably, the findings in this paper are robust to the inclusion of years 2000 and 2001.
} 
taxation in Croatia; before 1997 Croatia had a higher corporate tax rate, while after 2004 there were some further changes in dividend and personal taxation. ${ }^{7}$

We start with a sample of 71,748 firm/year observations for years 1998, 1999, 2002 and 2003. First, we drop 3,678 observations of financial firms, stateowned enterprises, publicly-traded firms, firms with consolidated statements, and firms operating in Free Trade Zones. ${ }^{8}$ Next, we drop 1,737 observations of firms with incomplete financial data. ${ }^{9}$ We also drop 43,824 observations with zero or less than 2 percent long-term debt to assets ratio since they represent special cases of firms that may not have access to long-term financing (typical of small infant firms or firms in remote post-conflict locations in transition countries), and as a result cannot be expected to reduce their debt levels as a result of the corporate tax reform. ${ }^{10}$ Finally, since tax benefits of debt exist only for profitable firms, the sample excludes 8,460 observations of firms that registered losses. ${ }^{11}$ Our final sample includes 14,049 firm-year observations. This sample of private Croatian companies reflects mostly micro and small

\footnotetext{
${ }^{7}$ The new Corporate Income Tax Act (NN 177/04) became effective from 1/1/2005. Further changes in corporate taxation were introduced in 2005 and 2006 (i.e., NN 90/05 and NN 57/06).

${ }^{8}$ Based on Croatia's Law on Free Zones (NN 44/96 and later NN 92/05), companies in Free Trade Zones enjoy special tax treatment. The initial Amadeus sample contained 233 firm-year observations from private companies operating in Free Trade Zones. Also, since $96.9 \%$ of the companies in our sample are micro and small firms, it is highly unlikely that these firms could have utilized tax incentives included in the Investment Incentives Law (NN No. 73/00), which offered tax reductions for investments of over $€ 1.5$ million that created at least ten new jobs.

${ }^{9}$ We can safely assume that the observations with missing data are random, given that t-tests between these firms and the firms in the final sample reveal no significant differences in the dependent and independent variables.

${ }^{10}$ Despite the arbitrary nature of the 2 percent cutoff rate, the results are robust to alternative cutoff rates (e.g., 5\%, 10\%). Importantly, our results are robust to the inclusion of these observations, but the magnitude of the effect is lower.

${ }^{11}$ Our results are robust to the inclusion of these observations (assuming that the effective tax rate of firms with losses is zero).
} 
firms (EU definition ${ }^{12}$ ). In the robustness checks we also include firms with registered losses or with 'LT Debt-to-Assets' ratio of less than 2 percent; both the significance and the sign of the findings from the reduced sample of 14,049 remain unchanged with the wider sample of 66,333 firms.

The central hypothesis tested in this paper is that capital structure choices change after a reduction in corporate taxes, ceteris paribus, due to decreasing tax shield benefits on earnings. In particular, based on the trade-off theory of debt, a decrease in corporate taxes reduces the optimal debt level. Moreover, this relation is expected to be stronger in smaller firms (due to arbitrage opportunities between personal and business taxation as well as higher bankruptcy probability compared to larger firms) and more profitable firms (because they are in better position to repay their existing debt and use retained earnings as marginal source of funding for investments).

In order to capture the effect of statutory tax change on capital structure, we utilize the accounting-based effective tax rate (ETR) -the ratio of income tax expense to pretax financial accounting income- which has been widely utilized in the taxation literature (Buijink et al., 2002; Callihan, 1994; Omer et al., 1991; Shackelford and Shevlin, 2001; Shevlin, 1999). Unlike the economictheory-based effective tax rates, this accounting-based ETR reflects the complexities of the tax system since it is based on the actual source of finance

\footnotetext{
12 Recommendation 2003/361/EC was adopted by the EU Commission and asserted firm size classification based on either employment, sales or assets. For instance, the assets criterion divides firms into micro (less than $€ 2 \mathrm{~m}$ ), small (between $€ 2 \mathrm{~m}$ and $€ 10 \mathrm{~m}$ ), medium (between $€ 10 \mathrm{~m}$ and $€ 43 \mathrm{~m}$ ) and large (over $€ 43 \mathrm{~m}$ ). Based on this criterion, the unbalanced panel employed in this research contains $83.6 \%$ micro, $13.3 \%$ small, $2.7 \%$ medium and $0.4 \%$ large firms.
} 
and asset structure of individual firms and accounts for the fact that some firms cannot always make use of all their allowances against tax (Chennels and Griffith, 1997), thus providing a measurement for actual overall tax burden of Croatian firms. Although the accounting-based ETR is firm-specific, it does reflect tax burden changes across the entire corporate sector since the aggregate ETR approximates the statutory tax rate. As shown in Figure 1, on average the ETR approximates the statutory tax rate $(35 \%$ and $20 \%$ before and after the reform, respectively) and small variations can be attributed to a variety of tax deductions/credits pertinent to specific incentives, accelerated depreciation, tax loss carry provisions, and tax penalties, among other reasons.

With respect to the empirical methodology, we apply the following panel-data specification with firm fixed-effects:

$$
Y_{i t}=\alpha_{i}+\beta \cdot X_{i t}+\gamma \cdot E T R_{t t}+\varepsilon_{i t}
$$

where $Y$ is interchangeably $\left(\frac{\text { Long term Debt }}{\text { Assets }}\right)$ and $\left(\frac{\text { Equity }}{\text { Assets }}\right), \alpha_{i}$ denotes firmspecific effects, $X$ is a vector of control variables, ETR is the accounting-based effective tax rate, and $\varepsilon$ denotes the residuals. ${ }^{13}$

Regarding control variables, we utilize a series of variables that have been found previously to influence financing decisions (i.e., non-tax explanations of

\footnotetext{
${ }^{13}$ We interchangeably utilize long-term debt and equity as dependent variables, since Amadeus does not clearly indicate short-term debt (i.e., variable 'Loans' under the category 'Current liabilities' uniformly contains missing observations) for Croatian firms. Nevertheless, these two dependent variables are sufficient to identify an effect of taxation reform on capital structure, since long-term debt is highly correlated with short-term debt, and the level of equity reflects nondebt liabilities with tax-relief capacity. Notably, in the case of the Croatian private firms included in the BvD Amadeus dataset, "Non-current liabilities" with "Long-term debt" could be considered equivalent, since the observations for "Other non-current liabilities" appear either zero or missing.
} 
capital structure). Firm size, in terms of the natural logarithm of total sales, captures the differences in informational and ex ante costs of financial distress (Bancel and Mittoo, 2004; Graham, 2000; Klapper et al., 2002). The ratio of 'fixed assets to total assets' influences the cost of debt due to collateral considerations (banks tackling moral hazard and adverse selection by seeking collateral - Graham, 2000; Stiglitz and Weiss, 1981), especially in transition countries were banks increasingly rely on hard information from financial statements rather than soft data gathered over time through relationship lending (Haas et al., 2007). Following Graham (2000), we use return on assets and current ratio as measures of cash flows and liquidity, respectively, which have a crucial effect on firm borrowing since firms with poor cash flows and liquidity are in higher need of debt. At the same time, firms with higher profitability can use retained profits thus relying less on external finance.

Table 1 Summary Statistics

\begin{tabular}{lrrrrrrrr}
\hline & \multicolumn{3}{c}{ Total sample } & \multicolumn{2}{c}{$\begin{array}{c}\text { Sample before tax } \\
\text { reform }\end{array}$} & \multicolumn{2}{c}{$\begin{array}{c}\text { Sample } \text { after } \\
\text { tax reform }\end{array}$} \\
\cline { 3 - 4 } & Mean & Median & S.D. & Mean & S.D. & Mean & S.D. \\
Sales (Kuna mil.) & 20.796 & 5.125 & 114.41 & 17.338 & 122.61 & 23.285 & 108.07 \\
Fixed assets/Total assets & 0.321 & 0.285 & 0.22 & 0.312 & 0.22 & 0.327 & 0.22 \\
Return on assets & 0.105 & 0.069 & 0.11 & 0.115 & 0.11 & 0.098 & 0.10 \\
Current ratio & 1.853 & 1.280 & 3.07 & 1.861 & 3.78 & 1.847 & 2.44 \\
Effective Tax Rate (ETR) & 0.307 & 0.270 & 0.16 & 0.372 & 0.15 & 0.258 & 0.15 \\
\hline
\end{tabular}

Note - Summary statistics are presented for the independent variables used in the regression analyses. The pooled sample contains an unbalanced panel of 14,049 observations for years 1998, 1999, 2002 and 2003. 'Before' and 'After' tax reform refer to 1998-1999 and 2002-2003 periods, respectively. Data were obtained from BvD Amadeus. Firm sales are calculated in local currency and adjusted for inflation. 
Table 1 presents the summary statistics for all the independent variables used in the estimations. In order to capture firm-specific costs of financial distress as well as managerial entrenchment, we introduce firm-specific effects (MacKieMason, 1990, Jensen, 1986). Moreover, with firm fixed-effects we effectively account for product market and industry considerations, which could influence firm capital structure due to industry concentration (Chevalier, 1995; Phillips, 1995), dependence on intangible or specialized assets (Rajan and Zingales, 1995; Titman and Wessels, 1988), location, and volatility of cash flows (Graham, 2000). Finally, year dummies are included in order to control for different economic cycles or other systemic changes.

\section{Analysis of results}

Table 2 reports the estimation results. The effective tax rate $(E T R)$ is positive and significant, both as a standalone and as an interaction term with the firm size, thus indicating that the tax reform in Croatia had a significant effect on firms' capital structure. Moreover, it is found that the effect of corporate tax reform is declining with firm size. Separate estimations for four size quartiles of firms (based on total assets) show that the effect is stronger and highly significant for firms in the two smallest categories, but becomes weaker and insignificant for the two larger categories. Larger firms seem to be less sensitive to the tax reform because they enjoy more tax exemptions, deductions and allowances (Kesner-Skreb et al., 2001), as well as regressive compliance 
costs due to corporate taxation (Blazic, 2004). The declining effect of taxation reform in larger firms is also confirmed by the positive and significant coefficient for the interaction between ETR and firm size. Also, as expected, the positive and significant effect from the interaction between ETR and accounting performance illustrates that after the tax reform the more profitable firms were particularly keen to reduce their debt levels.

Table 2 Regression analysis of 'LT Debt to Assets' ratio

\begin{tabular}{|c|c|c|c|c|c|c|c|}
\hline \multirow{3}{*}{$\begin{array}{l}\text { Independent } \\
\text { Variables }\end{array}$} & \multicolumn{7}{|c|}{ Dependent Variable: (LT Debt / Assets) } \\
\hline & \multicolumn{3}{|c|}{ Full Sample } & \multirow{2}{*}{$\begin{array}{c}\text { Q1: } \\
\text { (Smallest) } \\
(4)\end{array}$} & \multirow{2}{*}{$\begin{array}{c}\text { Q2 } \\
(5)\end{array}$} & \multirow{2}{*}{$\begin{array}{c}\text { Q3 } \\
(6)\end{array}$} & \multirow{2}{*}{$\begin{array}{c}\text { Q4: } \\
\text { (Largest) } \\
(7)\end{array}$} \\
\hline & (1) & (2) & (3) & & & & \\
\hline Intercept & $\begin{array}{l}0.118 * * \\
(2.23)\end{array}$ & $\begin{array}{r}-0.063 \\
(1.01)\end{array}$ & $\begin{array}{r}-0.057 \\
(0.91)\end{array}$ & $\begin{array}{l}-0.200 \\
(1.25)\end{array}$ & $\begin{array}{l}-0.145 \\
(0.63)\end{array}$ & $\begin{array}{l}-0.212 \\
(1.17)\end{array}$ & $\begin{array}{r}0.148 \\
(1.20)\end{array}$ \\
\hline $\ln$ (Sales) & $\begin{array}{l}-0.000 \\
(0.14)\end{array}$ & $\begin{array}{r}0.013 * * * \\
(3.29)\end{array}$ & $\begin{array}{r}0.013 * * * \\
(3.20)\end{array}$ & $\begin{array}{l}0.021 * \\
(1.91)\end{array}$ & $\begin{array}{l}0.015 \\
(1.00)\end{array}$ & $\begin{array}{l}0.019 * \\
(1.66)\end{array}$ & $\begin{array}{l}-0.003 \\
(0.40)\end{array}$ \\
\hline $\begin{array}{l}\text { Fixed assets / } \\
\text { Total assets }\end{array}$ & $\begin{array}{l}0.269 * * * \\
(23.49)\end{array}$ & $\begin{array}{r}0.275 * * * \\
(24.07)\end{array}$ & $\begin{array}{r}0.274 * * * \\
(24.05)\end{array}$ & $\begin{array}{l}0.336 * * * \\
(12.60)\end{array}$ & $\begin{array}{c}0.252 * * * \\
(9.06)\end{array}$ & $\begin{array}{c}0.304 * * * \\
(12.25)\end{array}$ & $\begin{array}{c}0.265 * * * \\
(11.26)\end{array}$ \\
\hline Return on assets & $\begin{array}{c}-0.123 * * * \\
(6.75)\end{array}$ & $\begin{array}{r}-0.16 * * * \\
(8.38)\end{array}$ & $\begin{array}{r}-0.23 * * * \\
(7.30)\end{array}$ & $\begin{array}{l}-0.095^{* *} \\
(2.48)\end{array}$ & $\begin{array}{c}-0.169 * * * \\
(3.81)\end{array}$ & $\begin{array}{c}-0.137 * * * \\
(3.55)\end{array}$ & $\begin{array}{c}-0.155 * * * \\
(3.44)\end{array}$ \\
\hline Current ratio & $\begin{array}{l}0.015 * * * \\
(20.56)\end{array}$ & $\begin{array}{r}0.016 * * * \\
(21.30)\end{array}$ & $\begin{array}{r}0.016 * * * \\
(21.36)\end{array}$ & $\begin{array}{l}0.014 * * * \\
(10.33)\end{array}$ & $\begin{array}{l}0.036^{* * * *} \\
(12.81)\end{array}$ & $\begin{array}{c}0.024 * * * \\
(9.71)\end{array}$ & $\begin{array}{c}0.012 * * * \\
(7.91)\end{array}$ \\
\hline ETR & $\begin{array}{c}0.037 * * * * \\
(3.96)\end{array}$ & $\begin{array}{r}0.198 * * \\
(2.08)\end{array}$ & $\begin{array}{r}0.165^{*} \\
(1.72)\end{array}$ & $\begin{array}{c}0.064 * * * \\
(2.70)\end{array}$ & $\begin{array}{l}0.056 * * \\
(2.39)\end{array}$ & $\begin{array}{l}0.030^{+} \\
(1.62)\end{array}$ & $\begin{array}{l}0.027^{+} \\
(1.62)\end{array}$ \\
\hline $\begin{array}{l}\text { ETR } \times \\
\ln (\text { Sales })\end{array}$ & - & $\begin{array}{r}-0.012 * * \\
(2.04)\end{array}$ & $\begin{array}{r}-0.011 * \\
(1.82)\end{array}$ & - & - & - & - \\
\hline $\begin{array}{l}\text { ETR } \times \text { Return } \\
\text { on assets }\end{array}$ & - & - & $\begin{array}{r}0.305 * * * \\
(2.87)\end{array}$ & - & - & - & - \\
\hline Firm fixed-effects & Yes & Yes & Yes & Yes & Yes & Yes & Yes \\
\hline Year effects & No & Yes & Yes & No & No & No & No \\
\hline Observations & 14049 & 14049 & 14049 & 3512 & 3512 & 3512 & 3513 \\
\hline$R^{2}$ & 0.189 & 0.167 & 0.167 & 0.194 & 0.211 & 0.187 & 0.140 \\
\hline
\end{tabular}

Notes: Fixed-effects regressions for an unbalanced panel of private (non-listed), unconsolidated, nonfinancial, non-state Croatian firms with positive return on assets, for the years 1998, 1999, 2002 and 2003. Observations for 2000 and 2001 are omitted because they reflect the transition period from one corporate tax regime to another. Absolute values of $t$-statistics are reported in parentheses. Asterisks represent statistical significance at the $1 \%(* * *), 5 \%(* *), 10 \%(*)$ and $15 \%(+)$ levels. Columns $4-7$ present results for the four size categories (i.e. quartiles) based on firm sales in each specific year. The median firm size (total sales) for each quartile is $(Q 1: 1.23),(Q 2: 3.29),(Q 3: 7.94)$ and $(Q 4: 30.14)$. The reported $\mathrm{R}^{2}$ does not include the effect of the firm dummies. 
The control variables also offer interesting findings. In line with theoretical predictions, firm performance, as measured by return on assets, has a negative effect on long-term debt. This negative relation indicates that firms fund internally using retained earnings. Also, the size, liquidity and portion of fixed assets in a firm are positively related to levels of long-term debt to assets since larger firms have more need for debt, while firms with higher liquidity and collateral capacity have easier access to debt.

Table 3 Regression analysis of 'Equity to Assets' ratio

\begin{tabular}{|c|c|c|c|}
\hline \multirow[b]{2}{*}{ Independent Variables } & \multicolumn{3}{|c|}{ Dependent Variable: (Equity/Assets) } \\
\hline & (1) & (2) & (3) \\
\hline Intercept & $\begin{array}{l}-0.001 \\
(0.03)\end{array}$ & $\begin{array}{l}0.581 * * * \\
(11.45)\end{array}$ & $\begin{array}{l}0.584 * * * * \\
(11.52)\end{array}$ \\
\hline $\ln ($ Sales $)$ & $\begin{array}{l}0.014 * * * \\
(4.58)\end{array}$ & $\begin{array}{l}-0.030 * * * \\
(9.32)\end{array}$ & $\begin{array}{l}-0.030 * * * \\
(9.38)\end{array}$ \\
\hline Fixed assets/Total assets & $\begin{array}{l}0.101 * * * \\
(9.95)\end{array}$ & $\begin{array}{l}0.071 \text { *** } \\
(7.67)\end{array}$ & $\begin{array}{l}0.071^{* * *} \\
(7.66)\end{array}$ \\
\hline Return on assets & $\begin{array}{l}0.324 * * * \\
(19.92)\end{array}$ & $\begin{array}{l}0.450 \text { *** } \\
(29.71)\end{array}$ & $\begin{array}{l}0.411^{\text {**** }} \\
(16.16)\end{array}$ \\
\hline Current ratio & $\begin{array}{l}0.013 \text { *** } \\
(19.91)\end{array}$ & $\begin{array}{l}0.011^{* * *} \\
(17.52)\end{array}$ & $\begin{array}{l}0.011^{\text {*** }} \\
(17.55)\end{array}$ \\
\hline ETR & $\begin{array}{l}-0.122 * * * * \\
(14.88)\end{array}$ & $\begin{array}{l}-0.134 * \\
(1.72)\end{array}$ & $\begin{array}{l}-0.152 * \\
(1.94)\end{array}$ \\
\hline ETR $\times \ln ($ Sales $)$ & - & $\begin{array}{l}0.009 * \\
(1.77)\end{array}$ & $\begin{array}{l}0.009 * \\
(1.90)\end{array}$ \\
\hline ETR $\times$ Return on assets & - & - & $\begin{array}{c}\text { 0.164* } \\
(1.90)\end{array}$ \\
\hline Firm effects & Yes & Yes & Yes \\
\hline Year effects & No & Yes & Yes \\
\hline Observations & 14049 & 14049 & 14049 \\
\hline$R^{2}$ & 0.226 & 0.176 & 0.177 \\
\hline
\end{tabular}

Note: see notes of Table 2 .

In order to further substantiate the results, we repeat estimation [1] using 'equity-over-assets' as the dependent variable. This specification is equivalent 
to using total liabilities to assets, which is a broader measure of borrowing, incorporating non-debt liabilities with tax-relief capacity and short-term debt. ${ }^{14}$ The results, presented in Table 3, show a significant negative relation between ETR and equity levels, meaning that equity levels increased after the corporate tax reform in 2001, particularly in smaller firms and more profitable firms. ${ }^{15}$ In sum, Tables 2 and 3 provide strong support that indeed equity (and not shortterm debt or any other form of liability) increased and long-term debt decreased in private Croatian firms as a result of the corporate tax reform in 2001.

In addition, as we pointed out in Section 3, we repeat the estimations including in the sample firms with negative performance (Table 4: Columns 1 and 3), as well as firms with 'LT Debt-to-Assets' ratio of less than 2 percent (Table 4: Columns 2 and 4). These companies were excluded from the initial estimations. Despite the dramatic increase of the sample, the sign and the significance of the findings remain the same, thus demonstrating the apparent effect of corporate tax reform on the Debt/Equity ratio of Croatian firms. Finally, our results are robust to:

- replacing the ETR variable with a lagged ETR variable to address possible forward timing of financing decisions (MacKie-Mason, 1990);

- performing alternative estimation methodologies such as quantile regression (see Appendix 1), and OLS with differences across the 2001 reform, such as $\Delta\left(\mathrm{X}_{t}-\mathrm{X}_{t-3}\right)$

\footnotetext{
${ }^{14}$ Equity is equivalent to the 'Total shareholders funds' variable in $\mathrm{B} v \mathrm{D}$ Amadeus and is the sum of capital stock, additional paid-in capital, reserves, retained earnings and premiums. It is verified that the this variable is equal to the difference between 'Total Assets' and 'Total Liabilities'.

${ }^{15}$ This increase in equity is particularly strong for additional paid-in capital, reserves, and retained earnings. This can be illustrated with separate estimations having 'Other shareholders funds' variable (from $\mathrm{B} v \mathrm{D}$ Amadeus) as a dependent variable. 'Other shareholders funds' is the sum of additional paid-in capital, reserves, retained earnings and premiums. Results available upon request.
} 
- utilizing alternative samples, such as a balanced panel to avoid attrition (see Appendix 2), or an unbalanced panel that includes observations from years 2000 and 2001.

Table 4 Robustness check - Inclusion of firms with losses and firms with low LT Debt/Assets ratio

\begin{tabular}{|c|c|c|c|c|}
\hline \multirow[b]{2}{*}{ Independent Variables } & \multicolumn{2}{|c|}{$\begin{array}{l}\text { Dependent Variable: } \\
\text { (LT Debt /Assets) }\end{array}$} & \multicolumn{2}{|c|}{$\begin{array}{l}\text { Dependent Variable: } \\
\text { (Equity/Assets) }\end{array}$} \\
\hline & (1) & (2) & (3) & (4) \\
\hline Intercept & $\begin{array}{l}0.451 * * * \\
(20.07)\end{array}$ & - & $\begin{array}{l}-0.141 * * * \\
(5.40)\end{array}$ & $\begin{array}{l}0.139 * * * \\
(7.84)\end{array}$ \\
\hline $\ln ($ Sales $)$ & $\begin{array}{l}-0.020 * * * \\
(17.76)\end{array}$ & $\begin{array}{l}0.057 * * * \\
(59.25)\end{array}$ & $\begin{array}{l}0.019 * * * \\
(14.95)\end{array}$ & $\begin{array}{l}-0.001 \\
(0.89)\end{array}$ \\
\hline Fixed assets/Total assets & $\begin{array}{l}0.212^{* * * *} \\
(25.38)\end{array}$ & $\begin{array}{l}0.476 * * * \\
(76.21)\end{array}$ & $\begin{array}{l}0.217 * * * \\
(24.02)\end{array}$ & $\begin{array}{l}0.255^{* * * *} \\
(38.16)\end{array}$ \\
\hline Return on assets & $\begin{array}{l}-0.179^{* * *} \\
(15.87)\end{array}$ & $\begin{array}{l}-0.222 * * * \\
(22.64)\end{array}$ & $\begin{array}{l}0.536^{* * *} \\
(38.63)\end{array}$ & $\begin{array}{l}0.519 * * * \\
(67.33)\end{array}$ \\
\hline Current ratio & $\begin{array}{l}0.016^{* * * *} \\
(12.69)\end{array}$ & $\begin{array}{l}0.014 * * * \\
(36.56)\end{array}$ & $\begin{array}{l}0.011 * * * \\
(6.67)\end{array}$ & $\begin{array}{l}0.023^{* * *} \\
(14.25)\end{array}$ \\
\hline ETR & $\begin{array}{l}0.026 * * * \\
(3.35)\end{array}$ & $\begin{array}{l}0.114 * * * \\
(14.74)\end{array}$ & $\begin{array}{l}-0.119 * * * \\
(14.57)\end{array}$ & $\begin{array}{l}-0.102 * * * \\
(19.46)\end{array}$ \\
\hline Industry effects & Yes & Yes & Yes & Yes \\
\hline Year effects & Yes & Yes & Yes & Yes \\
\hline Observations & 22509 & 66333 & 22509 & 66333 \\
\hline$R^{2}\left(\right.$ Pseudo- $\left.R^{2}\right)$ & 0.195 & $(0.250)$ & 0.276 & 0.323 \\
\hline
\end{tabular}

Note: OLS (columns 1, 3 and 4) and Tobit (col.2) regressions with firm clustering. Firms with negative returns are included and their ETR value is assumed to be equal to zero. All estimations include firm industry (2-digit SIC) and year effects (not shown). See also notes in Table 2.

\section{Conclusions}

Utilizing Croatia's corporate tax reform in 2001 as a natural experiment, this study suggests a significant effect of corporate taxation on capital structure by demonstrating that lower taxes in Croatia resulted in lower firm leverage. Overall, the corporate tax reform in Croatia provides strong evidence for a tax 
effect on firms' financing policy. These findings are consistent with the tradeoff theory of capital structure, which suggests that lower taxes decrease the incentive to hold debt due to decreasing interest tax deductibility. Notably, the current study focuses on the sign and the significance of the effect from tax reform without making any further claims on the magnitude of the change in debt/equity ratios, because the firm- and time-varying adjustment speed of capital structures complicates the exact identification and economic interpretation of a magnitude (Nivorozhkin, 2005).

From a policy perspective, it could be argued that the reduction in corporate debt after the corporate tax reform could have impacted firms' access to finance. Just like other transition economies, Croatia has a bank-based financial system where low levels of debt financing are typically a supply-side phenomenon given the preferential bank financing towards state-owned enterprises and large firms. By reducing the optimal debt level, the tax reform may have -indirectly- enhanced SMEs' access to finance. This was important since access to finance was one of the major obstacles for Croatian firms. More specifically, based on surveys from the European Bank of Reconstruction and Development (EBRD), the portion of private SMEs in Croatia that reported obtaining financing from banks as a major obstacle in their operations was reduced from $48 \%$ in 1999 to $28 \%$ in $2005 .{ }^{16}$ Besides access to finance, the observed post-reform reduction in the average of debt loading for the average SME may also have contributed to lowering the probability for default on its

\footnotetext{
${ }^{16}$ Source: EBRD - Business Environment and Enterprise Performance Survey for 1999 and 2005.
} 
debt. In fact, from 2000 to 2004, the bank 'non-performing loans to total loans' ratio in Croatia's banking sector was steadily reduced from $9.5 \%$ to $4.6 \%{ }^{17}$

The findings are also important from a policy perspective since they originate from SMEs at a time when the SME sector is a fast-growing and highly leveraged segment in transition European countries. Moreover, the finding that Croatian firms substantially increased their equity portion in their capital structure in the years immediately after the corporate tax reform indicates a speedy adjustment toward target financial leverage. Similarly, the statistically significant interactions between the effective tax rate and firm size/performance illustrate that firm-specific effects may also affect the rate of adjustment and explain the variation across firms (Flannery and Rangan, 2006).

This paper belongs to the growing empirical literature utilizing exogenous policy changes in firms' environment in order to examine the trade-off theory of debt, ${ }^{18}$ thus responding to Myers' (1984: p. 588) challenge during his presidential address to the American Finance Association in 1984, in which he stated, "I know of no study clearly demonstrating that a firm's tax status has predictable, material effects on its debt policy." The findings in this study promote the potential for innovative research on corporate taxation in transition economies, such as whether corporate tax reforms affect the long-run demand for capital and firms' investment patterns.

\footnotetext{
${ }^{17}$ Source: IMF - Global Financial Stability Report (2005).

${ }^{18}$ See Frank and Goyal (2008) for review of this literature.
} 


\section{References}

Ang, J., 1992. On the theory of finance for privately held firms. Journal of Small Business Finance 1: 185-203.

Auerbach, A.J., 2002. Taxation and corporate financial policy. In: Auerbach A.J., Feldstein M. (Eds.), Handbook of Public Economics, Volume 3, Chapter 19, North-Holland: Amsterdam, 1251-1292.

Ayers, B., Cloyd, C., Robinson, J., 2001. The influence of income taxes on use of inside and outside debt by small businesses. National Tax Journal 54: 27-56.

Bancel, F., Mittoo, U.R., 2004. Cross-country determinants of capital structure choice: A survey of European firms. Financial Management 33: 103-132.

Blažić, H., 2004. Tax compliance costs of small business in Croatia. Institute of Public Finance (Croatia), Occasional Paper No. 22.

Bratić, V., 2006. Tax expenditure in Croatia: Personal income, corporate income, real estate transfers and value added tax. Institute of Public Finance (Croatia), Occasional Paper No. 31.

Buijink, W., Janssen, B., Schols Y., 2002. Evidence of the effect of domicile on corporate average effective tax rates in the European Union. Journal of International Accounting, Auditing \& Taxation 11: 115-130.

Callihan, D., 1994. Corporate effective tax rates: a synthesis of the literature. Journal of Accounting Literature 13: 1-43.

Chennells, L., Griffith, R., 1997. Taxing profits in a changing world, Institute for Fiscal Studies: London.

Chevalier, J.A., 1995. Capital structure and product market competition: An empirical study of supermarket LBO's. American Economic Review 85: 415-435.

Devereux, M.P., Sorensen, P.B., 2005. The corporate income tax: International trends and options for fundamental reform. Paper prepared for OECD Committee on Fiscal Affairs.

Flannery, M.J., Rangan, K.P., 2006. Partial adjustment toward target capital structures. Journal of Financial Economics 79: 469-506.

Frank, M.Z., Goyal, V.K., 2008. Tradeoff and pecking order theories of debt. In: Eckbo B.E. (Ed.) Handbook of corporate finance: Empirical corporate finance, Volume 2, Chapter 12, North-Holland: Amsterdam.

Givoly, D., Hahn, C., Ofer, A.R., Sarig, O.H., 1992. Taxes and capital structure: Evidence from firms' response to the Tax Reform Act of 1986. Review of Financial Studies 5: 331-355. 
Gordon, R.H, Mackie-Mason, J., 1990. Effects of the Tax Reform Act of 1986 on corporate financial policy and organizational form. In: Slemrod J. (Ed.), Do taxes matter? The impact of the Tax Reform Act of 1986, MIT Press: Cambridge (MA), 91-131.

Graham, J.R., 2000. How big are the tax benefits of debt? Journal of Finance 55: 1901-1941.

Graham, J.R., Harvey, C., 2001. The theory and practice of corporate finance: Evidence from the field. Journal of Financial Economics 60: 187-243.

Haas, R., Ferreira, D., Taci, A., 2007. What determines banks' customer choice? Evidence from transition countries. EBRD Working Paper Series No. 104.

Jensen, M.C., 1986. The agency costs of free cash flow: Corporate finance and takeovers, American Economic Review 76: 323-329.

Keen, M., King, J., 2002. The Croatian profit tax: An ACE in practice. Fiscal Studies 23: 401-418.

Kesner-Skreb, M., Plese, I., Mikić, M., 2003. State aid to enterprises in Croatia in 2001. Institute of Public Finance, Occasional Paper No.18.

Klapper, L.F., Sarria-Allende, V., Sulla, V., 2002. SME financing in Eastern Europe, World Bank, Policy Research Working Paper Series \#2933.

Klemm, A., 2007. Allowances for corporate equity in practice. CESinfo Economic Studies 53: 1-34.

Kraft, E., 2000. The lending policies of Croatian banks: Results of the second CNB bank interview project. Croatian National Bank.

MacKie-Mason, J.K., 1990. Do taxes affect corporate financing decisions? Journal of Finance 45: 1471-1493.

Miller, M.H., 1977. Debt and taxes. Journal of Finance 32: 261-276.

Myers, S.C., 2003. Financing of corporations. In: Constantinides G.M., Harris M. and Stulz R. (Eds.), Handbook of the Economics of Finance, Chapter 14, North-Holland: Amsterdam, 215-253.

Myers, S.C., 1984. The capital structure puzzle. Journal of Finance 39: 575592.

Nivorozhkin, E., 2005. Financing choices of firms in EU accession countries. Emerging Markets Review 6: 138-169.

Omer, T., Molloy, K., Ziebart, D., 1991. Using financial statement information in the measurement of effective corporate tax rates. Journal of the American Taxation Association 13: 57-72.

Phillips, G.M., 1995. Increased debt and industry product markets: An empirical analysis. Journal of Financial Economics 37: 189-238. 
Poterba, J., Summers, L. 1985. The economic effects of dividend taxation. In: Altman E. and Subrahmanyan M. (Eds.) Recent developments in corporate finance, Dow Jones Irwin: New York.

Prasad, S.J., Green, C.J., Murinde, V., 2005. Company financial structure: A survey and implications for developing economies, In: Green C.J., Kirkpatrick C.H., Murinde V. (Eds.), Finance and development: Surveys of theory, evidence and policy, Edward Elgar: Cheltenham(UK).

Rajan, R.G., Zingales, L., 1995. What do we know about capital structure? Some evidence from international data. Journal of Finance 50: 14211460.

Shackelford, D.A., Shevlin, T., 2001. Empirical tax research in accounting. Journal of Accounting and Economics 31: 321-387.

Shevlin, T., 1999. A critique of Plesko's "An evaluation of alternative measures of corporate tax rates." University of Washington Working paper.

Stiglitz, J.E., Weiss, A., 1981. Credit rationing in markets with imperfect information. American Economic Review 71: 393-410.

Švaljek, S., 2005. The 2000 tax reform in Croatia: Causes and consequences. Ekonomski Pregled/Economic Review 56: 1217-1236.

Titman, S., Wessels, R., 1988. The determinants of capital structure. Journal of Finance 43: 1-19.

Zodrow, G.R., 1991. On the "traditional" and "new" views of dividend taxation. National Tax Journal 44: 497-509. 


\section{Appendix}

\section{A.1. Quantile regression estimates of the effect of corporate tax reform on 'Equity to Assets' ratio of Croatian private firms}

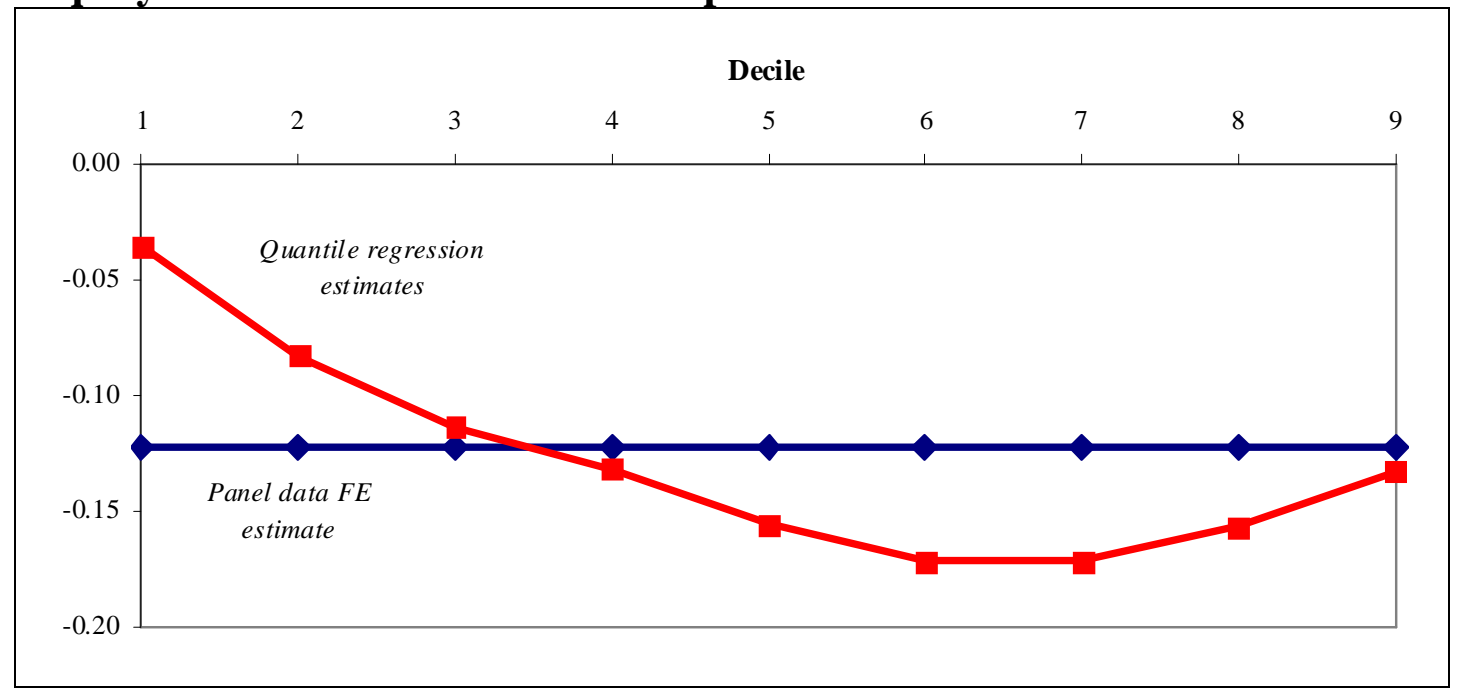

Note: The figure depicts the positive effect of tax reduction on equity (as a portion of equity in capital structure) due to the corporate tax reform. In particular, coefficients for the ETR variable from nine quantile regressions (at 0.10, 0.20, 0.30, 0.40, 0.50, 0.60, 0.70, 0.80, 0.90 quantiles) are plotted along with the coefficient from panel-data fixed-effects estimation effects (horizontal line). The sample and specification are the same with that utilized in Table 3 (Column 1). All estimates are significant at the 1 percent level

\section{A.2. Robustness check - Regression analysis with balanced panel}

\begin{tabular}{|c|c|c|c|c|}
\hline \multirow[b]{2}{*}{ Independent Variables } & \multicolumn{2}{|c|}{ Dependent: (LT Debt /Assets) } & \multicolumn{2}{|c|}{ Dependent: (Equity/Assets) } \\
\hline & (1) & (2) & $(3)$ & (4) \\
\hline Intercept & $\begin{array}{l}0.182 * * \\
(2.02)\end{array}$ & $\begin{array}{r}0.011 \\
(0.10)\end{array}$ & $\begin{array}{l}-0.125 \\
(1.53)\end{array}$ & $\begin{array}{c}0.117 \\
(1.26)\end{array}$ \\
\hline $\ln ($ Sales $)$ & $\begin{array}{l}-0.006 \\
(1.02)\end{array}$ & $\begin{array}{c}0.006 \\
(0.88)\end{array}$ & $\begin{array}{l}0.020 * * * \\
(3.98)\end{array}$ & $\begin{array}{l}0.004 \\
(0.67)\end{array}$ \\
\hline Fixed assets/Total assets & $\begin{array}{l}0.298 * * * \\
(15.57)\end{array}$ & $\begin{array}{l}0.303^{* * * *} \\
(15.86)\end{array}$ & $\begin{array}{l}0.123^{* * * *} \\
(7.14)\end{array}$ & $\begin{array}{l}0.117 * * * \\
(6.87)\end{array}$ \\
\hline Return on assets & $\begin{array}{l}-0.129 * * * \\
(4.30)\end{array}$ & $\begin{array}{l}-0.329 * * * \\
(6.32)\end{array}$ & $\begin{array}{l}0.291 * * * \\
(10.83)\end{array}$ & $\begin{array}{l}0.594 * * * \\
(12.77)\end{array}$ \\
\hline Current ratio & $\begin{array}{l}0.025^{* * *} \\
(13.18)\end{array}$ & $\begin{array}{l}0.026^{* * * *} \\
(13.89)\end{array}$ & $\begin{array}{l}0.033^{* * * *} \\
(19.69)\end{array}$ & $\begin{array}{l}0.031^{* * * *} \\
(18.42)\end{array}$ \\
\hline ETR & $\begin{array}{l}0.043 * * * \\
(2.72)\end{array}$ & $\begin{array}{c}0.297 * \\
(1.75)\end{array}$ & $\begin{array}{l}-0.161 * * * \\
(11.34)\end{array}$ & $\begin{array}{l}-0.491 * * * \\
(3.24)\end{array}$ \\
\hline ETR $\times \ln ($ Sales $)$ & - & $\begin{array}{l}-0.019 * \\
(1.82)\end{array}$ & - & $\begin{array}{l}0.025 * * * \\
(2.72)\end{array}$ \\
\hline ETR $\times$ Return on assets & - & $\begin{array}{l}0.777 * * * \\
(4.70)\end{array}$ & - & $\begin{array}{l}-1.171 * * * \\
(7.92)\end{array}$ \\
\hline Firm fixed-effects & Yes & Yes & Yes & Yes \\
\hline $\begin{array}{l}\text { Observations } \\
R^{2}\end{array}$ & $\begin{array}{l}3420 \\
0.162 \\
\end{array}$ & $\begin{array}{l}3420 \\
0.153 \\
\end{array}$ & $\begin{array}{l}3420 \\
0.343 \\
\end{array}$ & $\begin{array}{c}3420 \\
0.340 \\
\end{array}$ \\
\hline
\end{tabular}

Note: Fixed-effects regressions for a balanced panel of 855 private (non-listed), unconsolidated, nonfinancial, non-state Croatian firms with positive return on assets for years 1998, 1999, 2002 and 2003. See also notes in Table 2. 
Other papers in this series

Klapper, Leora and Tzioumis, Konstantinos, Taxation and Capital Structure: evidence from a transition economy, GreeSE Paper No16, July 2008

Monastiriotis, Vassilis, The Emergence of Regional Policy in Bulgaria: regional problems, EU influences and domestic constraints, GreeSE Paper No15, June 2008

Psycharis, Yannis, Public Spending Patterns:The Regional Allocation of Public Investment in Greece by Political Period, GreeSE Paper No14, May 2008

Tsakalotos, Euclid, Modernization and Centre-Left Dilemmas in Greece: the Revenge of the Underdogs, GreeSE Paper No13, April 2008

Blavoukos, Spyros and Pagoulatos, George, Fiscal Adjustment in Southern Europe: the Limits of EMU Conditionality, GreeSE Paper No12, March 2008

Featherstone, Kevin, 'Varieties of Capitalism' and the Greek case: explaining the constraints on domestic reform?. GreeSE Paper No11, February 2008

Monastiriotis, Vassilis, Quo Vadis Southeast Europe? EU Accession, Regional Cooperation and the need for a Balkan Development Strategy, GreeSE Paper No10, January 2008

Paraskevopoulos, Christos, Social Capital and Public Policy in Greece. GreeSE Paper No9, December 2007

Anastassopoulos George, Filippaios Fragkiskos and Phillips Paul, An 'eclectic' investigation of tourism multinationals' activities: Evidence from the Hotels and Hospitality Sector in Greece, GreeSE Paper No8, November 2007

Watson, Max, Growing Together? - Prospects for Economic Convergence and Reunification in Cyprus, GreeSE Paper No7, October 2007

Stavridis, Stelios, Anti-Americanism in Greece: reactions to the 11-S, Afghanistan and Iraq, GreeSE Paper No6, September 2007

Monastiriotis, Vassilis, Patterns of spatial association and their persistence across socio-economic indicators: the case of the Greek regions, GreeSE Paper No5, August 2007

Papaspyrou, Theodoros, Economic Policy in EMU: Community Framework, National Strategies and Greece, GreeSE Paper No4, July 2007

Zahariadis, Nikolaos, Subsidising Europe's Industry: is Greece the exception?, GreeSE Paper No3, June 2007

Dimitrakopoulos, Dionyssis, Institutions and the Implementation of EU Public Policy in Greece: the case of public procurement, GreeSE Paper No2, May 2007

Monastiriotis, Vassilis and Tsamis, Achilleas, Greece's new Balkan Economic Relations: policy shifts but no structural change, GreeSE Paper No1, April 2007

Other papers from the Hellenic Observatory

Papers from past series published by the Hellenic Observatory are available at http://www.lse.ac.uk/collections/hellenicObservatory/pubs/DP_oldseries.htm 